\title{
PEMBELAJARAN MATEMATIKA GASING DITINJAU DARI BERBAGAI PERSPEKTIF TEORI BELAJAR
}

\author{
Sulistiawati \\ STKIP Surya Tanggerang \\ email: sulistiawati@stkipsurya.ac.id
}

\begin{abstract}
ABSTRAK
Pembelajaran Matematika GASING lahir sebagai alternatif jawaban atas fakta bahwa matematika menjadi salah satu mata pelajaran yang ditakuti oleh siswa-siswa di Indonesia, sehingga siswa cenderung lemah dalam kemampuan konsep matematika. Tujuan penelitian ini untuk menyelidiki bagaimanakah Pembelajaran Matematika GASING jika ditinjau dari perspektif teori-teori belajar. Penelitian ini menggunakan metode penelitian kualitatif, jenis yang non interaktif tipe analisis konsep, yang dilakukan dengan penelaahan terhadap teori-teori. Hasil dari penelitian ini adalah Pembelajaran Matematika GASING memiliki kesesuaian dengan teori belajar behavioristik, humanistik, kognitif, dan konstruktivistik. Pembelajaran Matematika GASING sesuai dengan teori belajar behavioristik yang dikemukakan oleh Thorndike tentang hukum kesiapan, hukum latihan, dan hukum akibat. Selain itu, Pembelajaran Matematika GASING juga sesuai dengan teori belajar humanistik pemikiran Combs, yaitu siswa memiliki perasaan senang yang membuat siswa belajar sesuai kemauan sendiri tanpa terpaksa. Berikutnya, Pembelajaran Matematika GASING sesuai dengan teori belajar kognitif pemikiran Kohler, yaitu belajar dilakukan dengan cara bermain dan mengeksplorasi dengan benda nyata atau alat peraga (tahap konkret), proses mental atau mencongak siswa juga dapat menemukan jawaban atas persoalan yang dihadapi melalui faktor AHA (Insight). Lebih lanjut, Pembelajaran Matematika GASING sesuai dengan teori konstruktivistik Dewey, yaitu siswa terlibat aktif seperti yang terjadi pada proses pembelajaran tahap konkret, siswa melakukan hands on activity, sesuai dengan teori konstrukvistik Piaget bahwa siswa melibatkan indra penglihatan, pendengaran, perabaan, dan pengecapan dalam proses pembelajaran, dan juga sesuai dengan teori konstruktivistik Bruner yaitu discovery bahwa siswa dibimbing untuk menemukan konsep secara umum dari proses bukti secara induktif.
\end{abstract}

Kata Kunci: Pembelajaran Matematika GASING, Teori-Teori Belajar, Psikologi Pembelajaran, Titik Kritis GASING

Dikirim: 27 Februari 2019; Direvisi: 26 Maret 2019; Diterima: 26 Maret 2019

Cara sitasi: Sulistiawati. 2019. Pembelajaran Matematika Gasing Ditinjau dari Berbagai Perspektif Teori Belajar. Jurnal Teorema: Teori dan Riset Matematika. Vol 4 No 1, Hal 41-54, Maret 2019. 


\section{PENDAHULUAN}

Matematika GASING adalah suatu metode pembelajaran yang dikembangkan oleh Prof. Yohanes Surya, Ph.D. dari Surya Institute, Indonesia. Hal ini dilatarbelakangi oleh fakta bahwa matematika menjadi salah satu mata pelajaran yang ditakuti oleh siswa-siswa di Indonesia. Siswa cenderung lemah dalam kemampuan konsep matematika (Surya, 2013). Oleh karena itu diperlukan suatu alternatif cara untuk membuat siswa-siswa mudah belajar dan senang dalam menjalaninya. Matematika GASING memberikan kesempatan kepada siswa untuk belajar dengan pemahaman yang lebih terurut, step by step. Sejalan dengan pendapat yang diungkapkan oleh Sunaryo, Nuraida, \& Zakiah (2018) yang menyatakan bahwa sebelum siswa mampu berpikir tingkat tinggi maka siswa harus terlebih dahulu mampu berpikir tingkat rendah. Belajar dengan cara Matematika GASING yang disusun berurutan dari konsep termudah sampai yang tersulit dengan harapan siswa dapat dengan mudah memahami matematika sehingga dapat menemukan sendiri "AHA"nya.

Surya (Kusuma \& Sulistiawati, 2014) menyatakan bahwa GASING merupakan singkatan dari Gampang, Asylk, dan MenyenaNGkan. Sehingga Matematika GASING adalah belajar matematika dengan cara yang mudah sehingga siswa merasa Asyik dan senang dalam belajar matematika. Belajar dengan cara Matematika GASING memiliki 3 langkah yaitu konkret, abstrak, dan mencongak. Pada tahap konkret siswa belajar dengan bermain dan eksplorasi dengan benda nyata atau alat peraga. Pada tahap abstrak, siswa sudah melakukan proses matematika secara kognitif, seperti menggunakan simbol-simbol matematika. Hal ini sesuai dengan yang dinyatakan oleh teori belajar dari Piaget, Bruner, dan Dienes (Ibrahim \& Suparni, 2012). Pada tahap terakhir yaitu mencongak, siswa sudah dapat memahami konsep dan aplikasinya tanpa memerlukan alat bantu hitung dan dan bisa berpikir dengan cepat dan otomatis, sehingga siswa cenderung sudah hafal dan tinggal recall saja.

Dalam pembelajaran Matematika GASING terdapat istilah titik kritis yang dikenal dengan Titik Kritis GASING. Tititk kritis GASING merupakan satu titik yang harus dilewati oleh siswa atau seseorang yang sedang belajar Matematika GASING (Surya, 2013). Titik kritis GASING ini muncul pada topik-topik yang dipelajari. Untuk mencapai titik kritis GASING tersebut terdapat beberapa tahap materi yang harus dikuasai agar kemudian mahir dalam menjawab soal-soal didalamnya. Sebagai contoh pada topik penjumlahan, titik kritis GASINGnya adalah penjumlahan yang hasilnya kurang dari 20 seperti $8+7,6+9,8+8,9+9$, secara mencongak. Setelah siswa mencapai titik kritis GASING topik penjumlahan tersebut, siswa akan mampu menghitung penjumlahan berapa saja. Untuk mencapai titik kritis GASING penjumlahan tersebut ada langkah demi langkah yang harus dilalui oleh siswa. Langkah tersebut adalah: 1) mengenal bilangan 1-10, 2) penjumlahan yang hasilnya $1-10,3)$ mengenal bilangan 11-19, dan 4) penjumlahan yang hasilnya 11-19. Apabila siswa sudah menguasai keempat langkah tersebut dengan baik, maka dapat dikatakan bahwa siswa sudah masuk ke titik kritis GASING. Titik kritis GASING tersebut dapat digambarkan seperti anak tangga seperti pada Gambar 1.

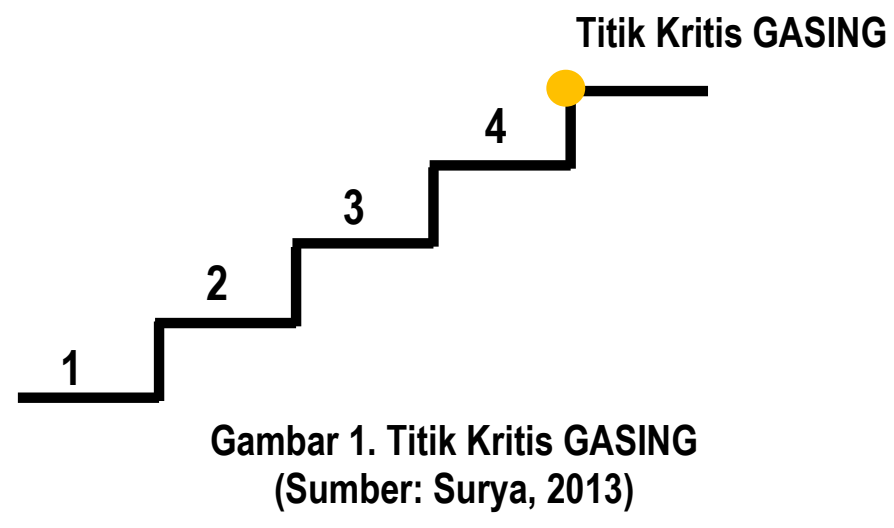

Dikirim: 27 Februari 2019; Direvisi: 26 Maret 2019; Diterima: 26 Maret 2019

Cara sitasi: Sulistiawati. 2019. Pembelajaran Matematika Gasing Ditinjau dari Berbagai Perspektif Teori Belajar. Jurnal Teorema: Teori dan Riset Matematika. Vol 4 No 1, Hal 41-54, Maret 2019. 
Sebagai suatu alternatif baru dalam pembelajaran Matematika, Matematika GASING perlu ditinjau dari beberapa perspektif teori belajar. Apakah sudah sesuai dengan karakter tumbuh kembang seorang anak. Dewasa ini kita telah mengenal beberapa teori belajar dengan paham yang berbeda-beda dan berbeda pula pendekatannya. Teori-teori belajar yang dibahas disini diantaranya: 1) teori belajar behavioristik, 2) teori belajar humanistik, 3) teori belajar kognitif, dan 4) teori belajar konstruktivistik.

Teori belajar behavioristik menjelaskan bahwa adanya perubahan tingkah laku dalam belajar merupakan akibat dari adanya interaksi antara stimulus dan respon yang menyebabkan siswa memiliki pengalaman baru (Nahar, 2016). Untuk teori belajar behavioristik, tokoh-tokohnya adalah Edward Lee Thorndike (1874-1949), Ivan P. Pavlov (1849-1936), dan Burrhus F. Skinner (19041990).

Thorndike menyatakan bahwa dasar dari belajar (learning) adalah asosiasi. Belajar itu adalah peristiwa terbentuknya asosiasi antara stimulus dan respon. Teori ini dikenal dengan teori Stimulus-Respon (S-R). Istilah lain dikenal dengan teori koneksionisme atau teori asosiasi. Stimulus atau rangsangan adalah perubahan dari lingkungan eksternal yang menggerakkan organisme untuk melakukan tindakan (beraksi), sedangkan respon adalah tingkah laku yang muncul karena adanya stimulus. Terjadinya stimulus dan respon mengikuti 3 hukum, yaitu: 1) law of readiness (hukum kesiapan), 2) law of exercise (hukum latihan), dan 3) law of effect (hukum akibat). Hukum kesiapan adalah apabila suatu organisme siap dalam memperoleh perubahan tingkah laku maka pelaksanaan tingkah laku tersebut akan menimbulkan kepuasan kepada individu sehingga asosiasinya akan diperkuat. Hukum latihan adalah apabila antara stimulus dan respon sering terjadi maka asosiasi yang terbentuk akan semakin kuat. Dengan kata lain semakin sering seseorang berlatih dengan pengetahuannya maka asosiasinya semakin kuat. Hukum akibat adalah stimulus dan respon yang membentuk asosiasi kemudian diikuti adanya kepuasan, maka kemungkinan asosiasi tersebut akan diulangi pada situasi yang mirip akan semakin meningkat. Hukum akibat ini dapat berupa tindakan dalam memberikan reward dan punishment kepada siswa.

Teori belajar beahavisoristik yang dikemukakan Pavlov dikenal dengan teori kondisioning atau refleks terkondisi (classical conditioning/ pembiasan klasikal). Pavlov melakukan percobaan pada anjing. Terrace (Mihmidiya, 2013) mengemukakan bahwa pembiasan klasikal merupakan pembiasaan untuk menciptakan refleks baru dilakukan dengan mendatangkan stimulus sebelum terjadinya refleks. Organisme belajar untuk mengasosiasikan stimuli, seperti stimulus netral (contoh: melihat seseorang) diasosiasikan dengan sesuatu yang bermakna (contoh: makanan), selanjutnya menimbulkan kapasitas untuk mengeluarkan kapasitas yang sama.

Dalam teori Pavlov, belajar adalah memasangkan antara stimulus lemah dengan stimulus kuat. Sebagai contoh, suara lagu dari penjual es krim Walls yang berkeliling dari rumah ke rumah, awalnya mungkin suara itu asing, tetapi setelah si pejual es krim sering lewat, maka nada lagu tersebut bisa menerbitkan air liur apalagi pada siang hari yang panas.

Teori yang dikemukakan oleh Skinner dikenal dengan behaviorisme radikal (Nahar, 2016). Skinner menyatakan belajar dikendalikan dengan operant conditioning. Maksudnya yaitu proses penguatan perilaku operan (positif atau negatif) dapat memberikan akibat perilaku yang berulang atau menghilag.

Teori belajar humanistik adalah belajar yang memanusiakan manusia. Penekanannya adalah manusia dapat mengaktualisasikan dan mengembangkan kemampuan dirinya untuk menghadapi kehidupan. Teori ini juga menekankan belajar yang tidak sekedar aspek kognitif tetapi juga aspek afektf, keduanya perlu dikembangkan. Oleh karena itu, pembelajaran memerlukan adanya motivasi baik dari dalam maupun dari luar individu agar dapat berjalan dengan baik. Individu diberi kebebasan untuk menentukan sendiri belajarnya. Selain itu teori humanistik juga mengutamakan insight.

Dikirim: 27 Februari 2019; Direvisi: 26 Maret 2019; Diterima: 26 Maret 2019

Cara sitasi: Sulistiawati. 2019. Pembelajaran Matematika Gasing Ditinjau dari Berbagai Perspektif Teori Belajar. Jurnal Teorema: Teori dan Riset Matematika. Vol 4 No 1, Hal 41-54, Maret 2019. 
Tokohnya teori belajar humanistik adalah Abraham Maslow dan Carl Rogers (1902), Arthur Combs. Sedangkan tokoh-teori kognisi sosial adalah Lev Vygotsky (1896-1934) dan Albert Bandura (1925-). Lev Vygostky terkanal dengan istilah scaffolding dan ZPD (Zone of Proximal Development).

Abraham Maslow mengungkapkan bahwa dalam diri individu ada 2 hal penting, yaitu: usaha yang positif untuk berkembang dan kekuatan untuk melawan perkembangan itu. Maslow menambahkan ada 5 kebutuhan pokok manusia yang disajikan secara hirarki seperti pada Gambar 2.

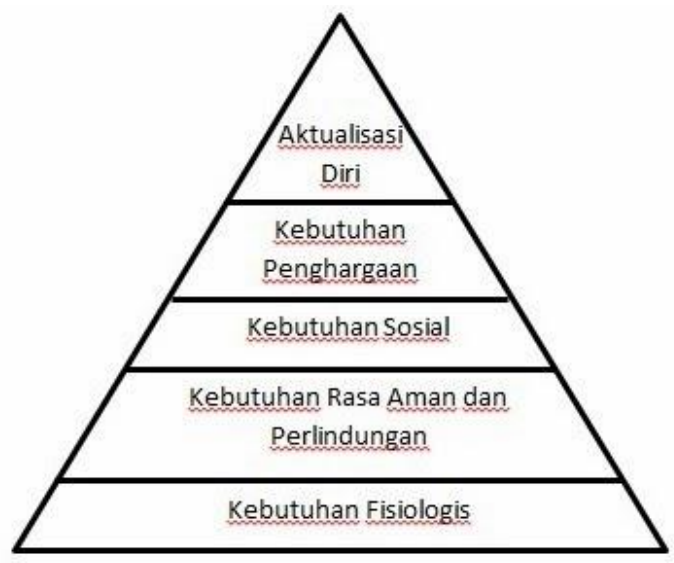

Gambar 2. Hirarki Kebutuhan Manusia Menurut Maslow

Carl Rogers membagi belajar dalam 2 tipe yaitu tipe kognitif (kebermaknaan) dan experiental (pengalaman). Rogers menyatakan bahwa belajar yang berguna secara sosial adalah belajar tentang proses belajar. Ada 4 kebutuhan individu yang harus dipenuhi yaitu: 1) pemeliharaan, 2) peningkatan diri, 3) penghargaan positif (positif regard), dan 4) penghargaan diri yang positif (positif self-regard).

Arthur Combs mengungkapka bahwa belajar akan berarti apabila memiliki arti bagi individu pembelajar. Individu dapat mengerti bagaimana alam atau dunia dari sudut pandangnya sendiri, bukan orang lain. Hal ini pastilah melibatkan perasaan, persepsi, kepercayaan, dan tujuan tingkah laku dari dalam diri individu yang membuat individu berbeda dari orang lain. Oleh karena itu, dalam belajar individu dapat memilih materi yang disukainya, dan guru tidak dapat memaksa materi yang tidak relevan dengan kehidupan mereka.

Scaffolding adalah dan ZPD adalah istilah yang sangat lekat dengan Lev Vygotsky. ZPD (Zone Proximal Development) adalah perkembangan seseorang sedikit diatas perkembangan saat ini. Vygotsky mengemukakan teori bahwa fungsi mental yang lebih tinggi pada seseorang, pada umumnya muncul dari percakapan atau kerjasama antar individu, sebelum fungsi mental yang lebih tinggi terserap dalam individu tersebut. Berikut gambaran ZPD oleh Vygotsky.

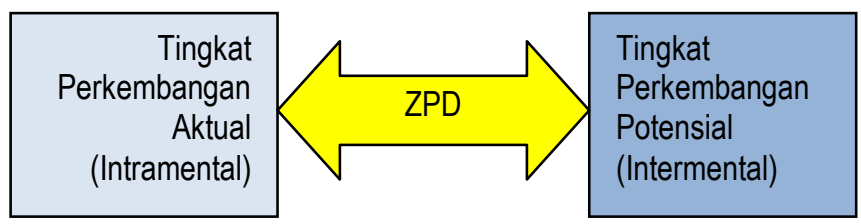

Gambar 3. Zone Proximal Development

Scaffolding berarti memberikan sejumlah besar bantuan kepada seorang anak selama tahap-tahap awal pembelajaran kemudian anak tersebut mengambil alih tangung jawab yang semakin besar segera setelah ia dapat melakukannya. Bantuan tersebut dapat berupa petunjuk, 
peringatan, dorongan, menguraikan masalah ke dalam langkah-langkah pembelajaran, memberikan contoh ataupun yang lain sehinggga memungkinkan siswa tumbuh mandiri.

Teori belajar humanistik yang dikemukakan oleh Bandura dikenal dengan teori pembelajaran social-kognitif, menyatakan bahwa belajar dilakukan melalui proses observasi atau mengamati dan juga meniru (Laila, 2015). Lebih lanjut, teori ini berdasarkan pada asusmsi bahwa: 1) Individu belajar melalui meniru yang ada di lingkungannya, dalam hal ini perilaku orang lain, 2) Pembelajaran melibatkan hubungan tiga pihak yaitu faktor pribadi individu, lingkungan, dan perilaku, dan 3) Perilaku sehari-hari merupakan hasil pembelajaran yang berupa perilaku visual dan verbal. Pemikiran Bandura berkaitan dengan pendidikan moral, yang berpandangan bahwa: 1) Pendidik merupakan model atau teladan yang baik bagi peserta didik dan peserta didik adalah subyek pendidikan yang memperhatikan model, 2) Lingkungan memiliki pengaruh besar dalam membentuk moral peserta didik, baik lingkungan keluarga, sekolah, maupun masyarakat. 3) Pendidikan moral dapat dilakukan dengan metode conditoning (pembiasaan) atau imitation (peniruan), yang mana seorang anak akan meniru suatu perilaku apakah memperoleh reward (hadiah) atau punishment (hukuman). Ada empat faktor yang terlibat dalam proses mengamati yaitu: 1) perhatian, 2) penyimpanan, 3) reproduksi motorik, dan 4) motivasi.

Untuk teori belajar kognitif tokoh yang berperan adalah Max Wertheimer (1880-1943), Kurt Koffka (1886-1941) dan Wolfgang Kohler (1887-1967). Wertheimer, Koffka, dan Kohler dijuluki tiga serangkai pendiri Teori Gestalt, dengan Wertheimer sebagai perintis/pemimpinnya. Wertheimer meneliti tentang persepsi yang teritegrasi dalam gerak, Kohler meneliti insight dalam simpanse, dan Koffka menguraikan tentang hukum-hukum persepsi secara lebih rinci (Hidayati, 2011).

Wertheimer terkenal dengan istilah Phi Phenomenon (Hidayati, 2011) yang menjelaskan bahwa apabila mata melihat perangsang dengan cara tertentu maka akan memberikan ilusi gerakan. Lebih jauh, Wertheimer mengembangkan teori persepsi yang disebut dengan teori Gestalt setelah mengamati "stroboscope". Wertheimer bereksperimen mengenai "gerak semu" yang memberi kesimpulan bahwa pengamatan mengandung hal yang melebihi jumlah unsur-unsurnya yang disebut dengan "gejala Gestalt". Hal ini kemudian dikaitkan dengan pembelajaran yang berlaku juga teori tersebut.

Kohler mencetuskan istilah insight. Istilah insight diartikan sebagai pengamatan atau pemahaman mendadak terhadap hubungan antar bagian dalam suatu permasalahan yang diamati. Istilah insight ini sering disebut juga dengan istilah AHA. Teorinya adalah bahwa dalam pemecahan suatu masalah seseorang melibatkan mental yang menggabungkan dan mengkombinasikan berbagai elemen dari masalah tersebut sampai masalah tersebut dapat dipecahkan (Triyanto, 2011).

Koffka dan Kohler bekerjasama dengan Wertheimer dalam menulis penelitian yang akhirnya dapat mempopulerkan teori Gestalt. Koffka sangat berperan dalam penyebarluasan prinsip-prinsip teori Gestalt melalui tulisannya "Grown of The Mind" dan "Principles of Gestalt Psychology" (Hidayati, 2011).

Untuk teori belajar konstruktivistik tokoh yang terlibat adalah John Dewey (1856-1952), Jean Piaget (1896-1980), dan Jerome Brunner (1915). Teori John Dewey dikenal dengan istilah Student Centered Learning (SCL). Maksud SCL adalah bahwa belajar harus bersifat aktif, siswa sebagai pusatnya dengan menggunakan pengalaman sosial dan guru bertindak sebagai fasilitator. Tujuan dari teori ini adalah munculnya kesadaran sosial pada diri individu yang belajar.

Piaget membahas tentang muncul dan diperolehnya schemata (skema). Skema yang dimaksud adalah bagaimana memberikan persepsi lingkungannya dalam tahapan perkembangannya. Skema tersebut terbagi dalam 4 periode yang digolongkan menurut usia. Periode tersebut, yaitu: 1) sensorimotor (0-2 tahun), 2) pra operasional (2-7 tahun), 3) operasi konkret (7-11 tahun) dan 4) operasi formal (11 tahun-dewasa). Periode sensorimotor menjadi penanda perkembangan kemampuan dan pemahaman spasial. Tahap sensorimotor ini dibagi

Dikirim: 27 Februari 2019; Direvisi: 26 Maret 2019; Diterima: 26 Maret 2019

Cara sitasi: Sulistiawati. 2019. Pembelajaran Matematika Gasing Ditinjau dari Berbagai Perspektif Teori Belajar. Jurnal Teorema: Teori dan Riset Matematika. Vol 4 No 1, Hal 41-54, Maret 2019. 
ke dalam 6 sub tahapan, yaitu a) skema refleks (berhubungan dengan refleks, muncul sejak lahir hingga usia 6 minggu), b) fase reaksi sirkular primer (berhubungan dengan munculnya kebiasaankebiasaan pada bayi, usia 6 minggu - 4 bulan), c) fase reaksi sirkular sekunder (berhubungan dengan koordinasi antara penglihatan dan pemaknaan, usia 4 bulan - 9 bulan), d) koordinasi reaksi sirkular sekunder (berkembangnya kemampuan melihat objek sebagai sesuatu yang permanen meskipun dilihat dari sudut yang berbeda-beda, usia 9 bulan - 12 bulan), e) fase reaksi sirkular tersier. Teori Jean Piaget menyatakan bahwa proses belajar melalui 3 tahap yaitu asimilisi, akomodasi, dan equilibrasi (penyeimbangan) dan guru bertindak sebagai fasilitator.

Jerome Brunner menyatakan bahwa belajar adalah upaya memberi kebebasan kepada siswa untuk belajar sendiri, menemukan sesuatu dengan caranya sendiri (discovery). Brunner dikenal dengan 3 tahap kognitif, yaitu 1) enaktif (0-3 tahun), 2) ikonik (3-8 tahun), 3) simbolik (lebih dari 8 tahun).

Berdasarkan uraian di atas penelitian ini bertujuan untuk menyelidiki bagaimanakah Pembelajaran Matematika GASING jika ditinjau dari perspektif teori-teori belajar tersebut. Untuk menjelaskan hal ini, dipaparkan karakteristik Matematika GASING yang berhubungan dengan teoriteori belajar tersebut.

\section{METODE PENELITIAN}

Penelitian ini menggunakan metode penelitian kualitatif. Jenis yang digunakan adalah non interaktif tipe analisis konsep. Hal ini dilakukan dengan penelaahan terhadap teori-teori, yaitu tentang Matematika GASING dan teori-teori belajar. Proses yang dilakukan adalah dengan penelaahan secara mendalam, membandingkan, dan mencari kaitan antara Matematika GASING dengan teori belajar behavioristik, teori belajar humanistik, teori belajar kognitif, dan teori belajar konstruktivistik.

\section{HASIL DAN PEMBAHASAN}

Matematika GASING memiliki karakter pembelajaran melaui tahap konkret, abstrak, dan mencongak. Dalam proses tersebut siswa diarahkan untuk menemukan sendiri pengetahuan barunya. Hal ini sesuai dengan trend pembelajaran yang dikembangkan oleh ahli melalui teori-teori belajar. Pembelajaran Matematika GASING didukung oleh beberapa teori belajar, diantaranya : 1) teori belajar behavioristik, 2) teori belajar humanistik, 3) teori belajar kognitif, dan 4) teori belajar konstruktivistik.

Pembahasan pertama menganai Pembelajaran Matematika GASING dan Teori Behavioristik. Dalam teori behavioristik yang dikemukakan Thorndike berlaku hukum kesiapan, hukum latihan, dan hukum akibat. Hal ini ternyata terjadi di dalam pembelajaran Matematika GASING. Dalam hukum kesiapan, apabila individu siap dalam menghadapi perubahan tingkah laku maka akan menimbulkan kepuasan. Kepuasan ini muncul ketika siswa merasa senang, mereka menemukan faktor AHA, bisa tertawa, terpuaskan rasa ingin tahunya/faktor AHA, dan merasa gembira. Hal ini merupakan ciri dari belajar menyenangkan (Surya \& Moss, 2012). Dalam hukum latihan, asosiasi akan semakin kuat apabila sering dilatih. Hal ini terjadi dalam pembelajaran Matematika GASING, yang mana setelah seseorang menguasai konsep dalam Matematika GASING, dalam arti mengerti bentuk konkret, abstrak, dan cara mencongaknya maka akan diberikan latihan secara lisan dan tertulis yang berulang-ulang untuk memperlancar kemampuan mencongaknya. Dengan latihan ini pemahaman yang dimiliki akan semakin kuat, setelah itu akan diarahkan kepada soal atau masalah yang lebih tinggi, seperti soal cerita dan soal pemecahan masalah. Dalam hukum akibat, misalnya adanya reward dan punishment. Dalam pembelajaran Matematika GASING, ketika siswa mampu mengerjakan atau menjawab pertanya diberikan pujian

Dikirim: 27 Februari 2019; Direvisi: 26 Maret 2019; Diterima: 26 Maret 2019

Cara sitasi: Sulistiawati. 2019. Pembelajaran Matematika Gasing Ditinjau dari Berbagai Perspektif Teori Belajar. Jurnal Teorema: Teori dan Riset Matematika. Vol 4 No 1, Hal 41-54, Maret 2019. 
secara verbal dan non verbal, seperti kata "Kamu benar" atau "Bagus" sembari mengacungkan jempol.

Pembahasan kedua mengenai Pembelajaran Matematika GASING dan Teori Humanistik. Teori humanistik menekankan belajar yang sesuai dengan keadaan individunya, memanusiakan manusia. Sebagai contoh, dalam teori belajar Combs bahwa belajar dapat saja melibatkan perasaan. Hal ini muncul dalam pembelajaran Matematika GASING, yaitu siswa memiliki perasaan senang. Jika senang, siswa akan belajar atau mengerjakan sesuatu berdasarkan kemauannya sendiri tanpa adanya paksaan dari orang lain (Surya \& Moss, 2012). Selain itu, menurut Rogers bahwa belajar harus bermakna melalui proses mengalami atau experiental, sebagai contoh dalam Pembelajaran Matematika GASING siswa diajak bereksplorasi sebelum mendapatkan konsep secara abstrak. Sebagai contoh, pada pembelajaran keliling bangun datar siswa diajak bereksplorasi dengan batang korek api untuk menemukan konsep keliling.

- 14 batang korek api hendak dibuat persegi panjang. Ada berapa bentuk persegi panjang yang terjadi?
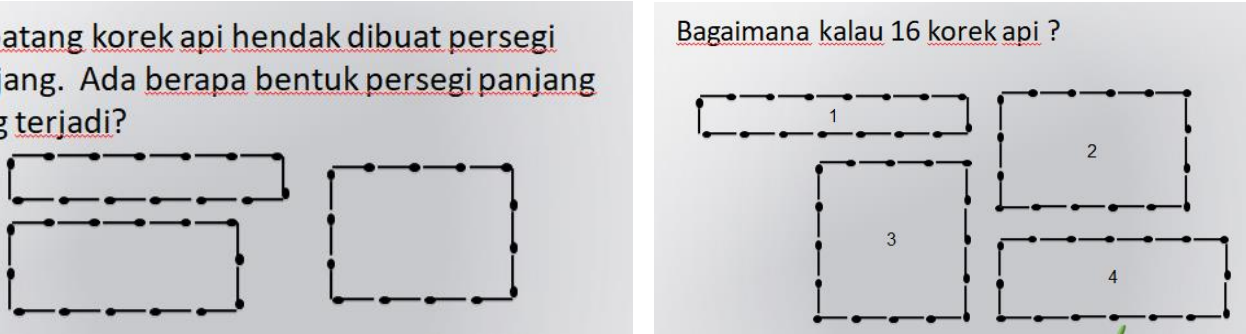

Gambar 4. Ilustrasi Eksplorasi dengan Batang Korek Api untuk Menemukan Konsep Keliling (Sumber: Surya, 2013)

Pembahasan ketiga mengenai Pembelajaran Matematika GASING dan Teori Kognitif. Dalam teori kognitif Kohler, siswa memiliki karakter sebagai pembelajar yang aktif, mereka mencari dan menemukan sendiri faktor "AHA" atau insight (Triyanto, 2011). Agar faktor AHA ini dapat muncul, kegiatan yang dapat dilakukan adalah mengeksplorasi, memanipulasi, bereksperimen, dan bertanya dan menjawab sendiri. Teori kognitif menekankan kepada adanya aktifitas siswa. Esensi dari teori kognitif ini sangat sesuai dengan yang dikehendaki dalam Pembelajaran Matematika GASING, yang mana dalam Matematika GASING belajar dilakukan dengan cara bermain dan mengeksplorasi dengan benda nyata atau alat peraga (tahap konkret). Sebagai contoh pada materi penjumlahan, pada tahap "pengenalan bilangan" siswa diajak memegang buah apel atau gambar buah apel dan memperhatikan banyaknya (jumlahnya). Secara konkret "satu" dapat dieksplor dengan menunjukkan satu buah apel, "dua" dieksplor dengan menunjukkan dua buah apel, dan seterusnya. Setelah siswa memahami konsepnya, mereka dikenalkan dengan simbolnya (tahap abstrak), seperti "satu" dapat dituliskan dengan simbol "1" dan "dua" dapat dituliskan dengan simbol "2", dan seterusnya. Berikut adalah gambaran eksplorasi pengenalan bilangan dari tahap konkret dan tahap abstrak.

Tabel 1. Konkret dan Abstrak Pengenalan Bilangan 1-10

\begin{tabular}{|c|c|c|}
\hline Bilangan & Bentuk Konkret & Bentuk Abstrak \\
\hline Satu & & 1 \\
\hline Dua & & 2 \\
\hline Tiga & & 3 \\
\hline Empat & & 4 \\
\hline Lima & & 5 \\
\hline
\end{tabular}

Dikirim: 27 Februari 2019; Direvisi: 26 Maret 2019; Diterima: 26 Maret 2019

Cara sitasi: Sulistiawati. 2019. Pembelajaran Matematika Gasing Ditinjau dari Berbagai Perspektif Teori Belajar. Jurnal Teorema: Teori dan Riset Matematika. Vol 4 No 1, Hal 41-54, Maret 2019. 


\begin{tabular}{|c|c|c|}
\hline Bilangan & Bentuk Konkret & Bentuk Abstrak \\
\hline Enam & & 6 \\
\hline Tujuh & & 7 \\
\hline Delapan & & 8 \\
\hline Sembilan & & 9 \\
\hline Sepuluh & & 10 \\
\hline
\end{tabular}

Tahap konkret dan abstrak ini sesuai dengan teori belajar kognitif yang dikemukakan oleh Piaget, Bruner, dan Dienes (Ibrahim \& Suparni, 2012). Setelah tahap abstrak, kemudian tahap mencongak. Dalam tahap mencongak "pengenalan bilangan", dalam Matematika GASING, digunakan peragaan jari, siswa dapat dengan cepat menunjukkan jari-jari saat diminta menunjukkan bilangan tertentu. Sebagai gambaran dapat pada gambar peragaan jari berikut.

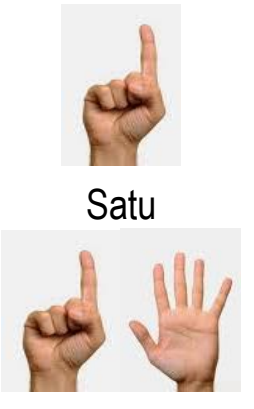

Enam

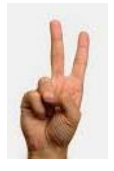

Dua

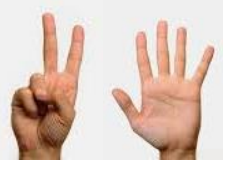

Tujuh

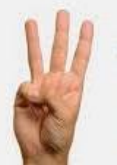

Tiga

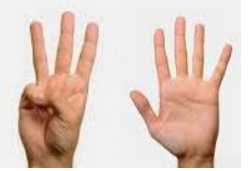

Delapan

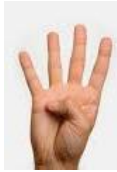

Empat

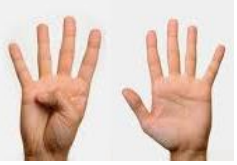

Sembilan

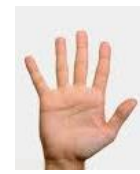

Lima

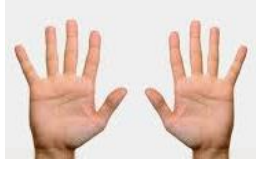

Sepuluh

\section{Gambar 5. Pengenalan Bilangan 1-10 dengan Jari-jari}

(Sumber: Surya, 2013)

Mencongak merupakan aktivitas mental yang dikaitkan dengan menghitung. Menurut KBBI (2018) mencongak diartikan menghitung di luar kepala (dengan ingatan saja, yang ditulis hasilnya saja). Anak yang mencongak berarti dia mampu melakukan perhitungan tanpa menggunakan pensil dan kertas atau alat bantu lainnya. Dalam Matematika GASING, proses pembelajaran mengharuskan siswa mampu berhitung dengan mencongak, dengan harapan siswa tersebut nantinya dapat mengerjakan jenis soal apa saja. Teori belajar yang mengungkapkan bahwa belajar melibatkan proses mental adalah teori kognitif oleh Wolfgang Kohler (Triyanto, 2011).

Dalam proses mental siswa juga dapat menemukan jawaban atas persoalan yang dihadapi. Jawaban ini ditemukan sendiri oleh siswa melalui faktor AHA (Insight), Contoh AHA yang dapat ditemukan siswa dalam pembelajaran Matematika GASING adalah pada materi Bilangan Bulat. Tentang perkalian billangan bulat negatif.

$$
\begin{aligned}
& -2 \times 2=-4 \\
& -2 \times 1=-2 \\
& -2 \times 0=0 \\
& -2 \times-1=2 \\
& -2 \times-2=4
\end{aligned}
$$

Disini siswa menemukan jawaban berdasarkan pola yang diamatinya. Dimana dari jawaban, selalu memiliki pola naik bertambah 2, sehingga dari contoh ini dapat simpulkan bahwa "biilangan negatif dikalikan bilangan negatif hasilnya bilangan positif". 
Pembahasan keempat mengenai Pembelajaran Matematika GASING dan Teori Konstruktivis. Tokoh konstruktivis Dewey menyatakan bahwa dalam belajar siswa harus terlibat aktif (student centered learning). Hal ini muncul dalam Pembelajaran Matematika GASING. Hal ini muncul pada tahap konkret, siswa selalu diarahkan untuk eksplorasi, dalam arti melakukan kegiatan dengan aktifitas tangan (hands on activity) atau fisik. Contoh dalam pengenalan bilangan 1-10 yang menggunakan jari-jari tangan, secara umum dalam operasi penjumlahan, perkalian, pengurangan, dan pembagian melibatkan aktifitas fisik. Selain itu pada saat pembuktian volume bangun ruang juga menggunakan peragaan, yang melibatkan aktifitas fisik, sehingga siswa lebih aktif.

Piaget membahas tentang muncul dan diperolehnya schemata (skema). Skema yang dimaksud adalah bagaimana memberikan persepsi lingkungannya dalam tahapan perkembangannya. Lebih lanjut, Piaget menyatakan bahwa pembelajaran harus melibatkan seluruh indra, sehingga pembelajaran akan membekas dan dapat disimpan lebih lama. Prosesnya melalui asimilasi, akomodasi, ekuilibrasi (penyeimbangan). Dalam pembelajaran Matematika GASING, tidak hanya melibatkan mata dan telinga (audio-visual), namun juga melibatkan peraba. Indra penglihatan sudah pasti pada saat siswa mengamati, indra pendengaran pada saat mendengarkan, dan indra perabaan pada saat siswa memegang alat peraga. Dalam indra pendengaran, untuk mempermudah siswa mengingat digunakan lagu yang dinyanyikan bersama-sama dengan nada lagu yang familiar atau populer di kalangan anak-anak. Dengan mengucapkan lagu berarti indra pengecapana juga terlibat. Sebagai contoh adalah "Lagu Perkalian Lima" dengan nada "Twinkle-twinkle Little Star", seperti berikut.

\section{Lima spuluh lima belas \\ Dua puluh dua lima \\ Tiga puluh tiga lima \\ Empat puluh empat Lima \\ Itu perkalian lima \\ Sangat mudah sekali}

Bruner melalui penemuan sendiri oleh siswa (discovery), hal ini terdapat dalam pembelajaran Matematia GASING. Sebagai contoh dalam pembelajaran luas bangun datar. Pembelajaran diawali pengenalan konsep luas dan satuan luas secara konkret melalui gambar yang dapat dibayangkan. Sebagai contoh dapat dilihat pada ilustrasi berikut.

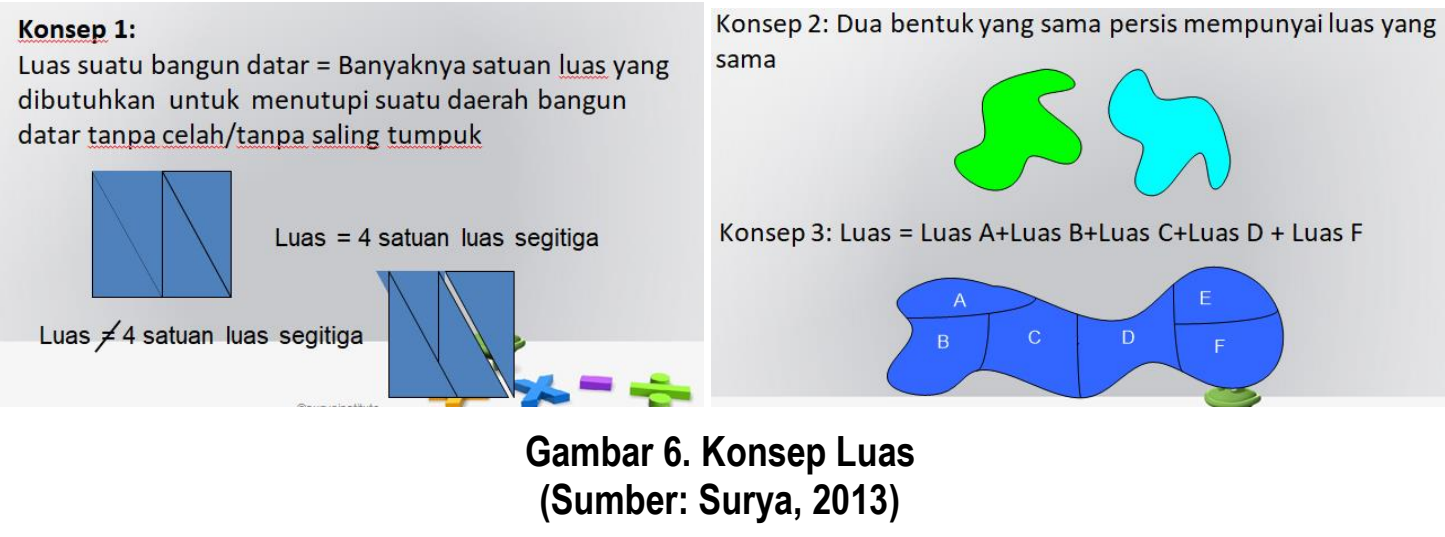

Dikirim: 27 Februari 2019; Direvisi: 26 Maret 2019; Diterima: 26 Maret 2019

Cara sitasi: Sulistiawati. 2019. Pembelajaran Matematika Gasing Ditinjau dari Berbagai Perspektif Teori Belajar. Jurnal Teorema: Teori dan Riset Matematika. Vol 4 No 1, Hal 41-54, Maret 2019. 


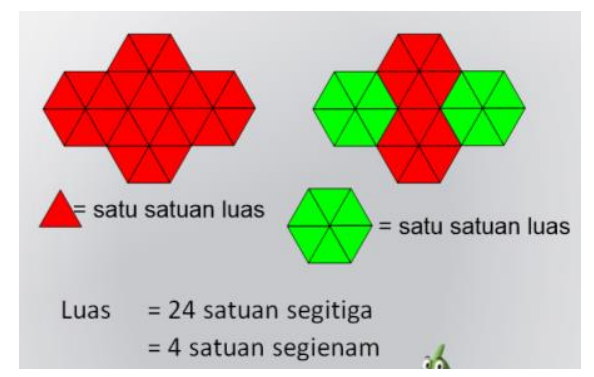

\section{Gambar 7. Konsep Satuan Luas (Sumber: Surya, 2013)}

Pengenalan konsep luas dan satuan luas di atas dilakukan dengan alat peraga (benda konkret). Tujuannya adalah agar siswa dapat menemukan sendiri makna dari luas atau "apa itu luas?". Penemuan sendiri suatu pengetahuan baru oleh siswa ini sangat sesuai konsep teori belajar Bruner, bahwa belajar adalah upaya memberi kebebasan kepada siswa untuk belajar sendiri, menemukan sesuatu dengan caranya sendiri (discovery). Disamping itu, belajar menjadi lebih bermakna sehingga pengetahuan baru dapat disimpan dalam memori lebih lama sesuai dengan teori Pavlov (Mihmidiya, 2013).

Lebih jelas sebagai contoh bahwa siswa diarahkan untuk menemukan sendiri suatu konsep dapat dilihat pada bagaimana sajian pembelajaran mengarahkan siswa untuk menemukan rumus luas dari bangun persegi panjang. Sebelumnya, sudah dilakukan kesepakatan bahwa satuan luas adalah kotak berbentuk persegi. Contohnya simbol persegi " $\square$ " mewakili satu satuan luas ( dalam hal ini $1 \mathrm{~cm}^{2}$ ). Maka sajian pembelajaran diarahkan seperti pada penjelasan berikut ini.

\begin{tabular}{|l|l|l|l|}
\hline $1 \mathrm{~cm}^{2}$ & $1 \mathrm{~cm}^{2}$ & $1 \mathrm{~cm}^{2}$ & $1 \mathrm{~cm}^{2}$ \\
\hline $1 \mathrm{~cm}^{2}$ & $1 \mathrm{~cm}^{2}$ & $1 \mathrm{~cm}^{2}$ & $1 \mathrm{~cm}^{2}$ \\
\hline
\end{tabular}

\begin{tabular}{|l|l|l|l|l|l|l|l|}
\hline $1 \mathrm{~cm}^{2}$ & $1 \mathrm{~cm}^{2}$ & $1 \mathrm{~cm}^{2}$ & $1 \mathrm{~cm}^{2}$ & $1 \mathrm{~cm}^{2}$ & $1 \mathrm{~cm}^{2}$ & $1 \mathrm{~cm}^{2}$ & $1 \mathrm{~cm}^{2}$ \\
\hline $1 \mathrm{~cm}^{2}$ & $1 \mathrm{~cm}^{2}$ & $1 \mathrm{~cm}^{2}$ & $1 \mathrm{~cm}^{2}$ & $1 \mathrm{~cm}^{2}$ & $1 \mathrm{~cm}^{2}$ & $1 \mathrm{~cm}^{2}$ & $1 \mathrm{~cm}^{2}$ \\
\hline
\end{tabular}

\begin{tabular}{|l|l|l|l|}
\hline $1 \mathrm{~cm}^{2}$ & $1 \mathrm{~cm}^{2}$ & $1 \mathrm{~cm}^{2}$ & $1 \mathrm{~cm}^{2}$ \\
\hline $1 \mathrm{~cm}^{2}$ & $1 \mathrm{~cm}^{2}$ & $1 \mathrm{~cm}^{2}$ & $1 \mathrm{~cm}^{2}$ \\
\hline $1 \mathrm{~cm}^{2}$ & $1 \mathrm{~cm}^{2}$ & $1 \mathrm{~cm}^{2}$ & $1 \mathrm{~cm}^{2}$ \\
\hline $1 \mathrm{~cm}^{2}$ & $1 \mathrm{~cm}^{2}$ & $1 \mathrm{~cm}^{2}$ & $1 \mathrm{~cm}^{2}$ \\
\hline
\end{tabular}

\begin{tabular}{|l|l|l|l|l|l|l|l|}
\hline $1 \mathrm{~cm}^{2}$ & $1 \mathrm{~cm}^{2}$ & $1 \mathrm{~cm}^{2}$ & $1 \mathrm{~cm}^{2}$ & $1 \mathrm{~cm}^{2}$ & $1 \mathrm{~cm}^{2}$ & $1 \mathrm{~cm}^{2}$ & $1 \mathrm{~cm}^{2}$ \\
\hline $1 \mathrm{~cm}^{2}$ & $1 \mathrm{~cm}{ }^{2}$ & $1 \mathrm{~cm}{ }^{2}$ & $1 \mathrm{~cm}^{2}$ & $1 \mathrm{~cm}^{2}$ & $1 \mathrm{~cm}^{2}$ & $1 \mathrm{~cm}^{2}$ & $1 \mathrm{~cm}^{2}$ \\
\hline $1 \mathrm{~cm}^{2}$ & $1 \mathrm{~cm}{ }^{2}$ & $1 \mathrm{~cm}{ }^{2}$ & $1 \mathrm{~cm}^{2}$ & $1 \mathrm{~cm}^{2}$ & $1 \mathrm{~cm}^{2}$ & $1 \mathrm{~cm}^{2}$ & $1 \mathrm{~cm}^{2}$ \\
\hline $1 \mathrm{~cm}^{2}$ & $1 \mathrm{~cm}^{2}$ & $1 \mathrm{~cm}^{2}$ & $1 \mathrm{~cm}^{2}$ & $1 \mathrm{~cm}^{2}$ & $1 \mathrm{~cm}^{2}$ & $1 \mathrm{~cm}^{2}$ & $1 \mathrm{~cm}^{2}$ \\
\hline
\end{tabular}

Luas bangun datar terdiri dari 8 kotak kecil dengan luas $1 \mathrm{~cm}^{2}$, jadi luas bangun datar $8 \mathrm{~cm}^{2}$

Luas bangun datar terdiri dari 16 kotak kecil dengan luas $1 \mathrm{~cm}^{2}$, jadi luas bangun datar $16 \mathrm{~cm}^{2}$

\section{Gambar 8. Sajian untuk Menemukan Konsep Luas Persegi Panjang (Sumber: Surya, 2013)}

Dikirim: 27 Februari 2019; Direvisi: 26 Maret 2019; Diterima: 26 Maret 2019

Cara sitasi: Sulistiawati. 2019. Pembelajaran Matematika Gasing Ditinjau dari Berbagai Perspektif Teori Belajar. Jurnal Teorema: Teori dan Riset Matematika. Vol 4 No 1, Hal 41-54, Maret 2019. 
Dengan proses mengamati dan mengeksplorasi, para peserta didik pada akhirnya dapat mengenali bahwa untuk mendapatkan luas bangun yang diminta dapat dilakukan dengan cara yang lebih cepat daripada menghitung satu-satu, yaitu dengan melihat ukuran persegi panjang yang ditampilkan. Peserta didik dapat menemukan bahwa hasil luas persegi panjang dengan menghitung satu-satu dan dengan mengalikan panjang sisi tegak (banyak kolom) dan sisi mendatar (banyak baris) adalah sama. Kesimpulan ini ditemukan sendiri oleh siswa.

Setelah proses di atas, peserta didik diberikan bangun persegi panjang dengan ukuran panjang sisi tegak dan panjang sisi datar, tanpa kotak kecil satu satuan luas $\left(1 \mathrm{~cm}^{2}\right)$. Peserta didik dapat dengan cepat mendapatkan hasil luas persegi panjang dengan mengalikan.

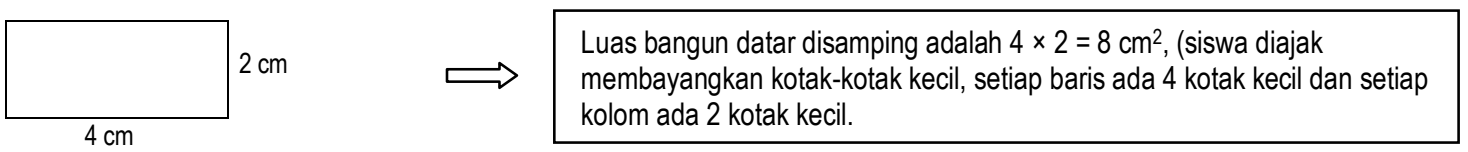

\section{Gambar 9. Persegi Panjang dengan Konsep Menemukan Luasnya Menggunakan Bayangan Kotak-kotak Kecil di dalamnya}

Hal ini dapat dilakukan dengan beberapa contoh, sampai siswa mengerti sehingga tidak perlu lagi dipandu untuk membayangkan banyak kotak kecil pada setiap kolom dan setiap baris pada gambar persegi panjang. Kemudian dilanjutkan lagi dengan contoh lain, misalnya seperti di bawah ini.

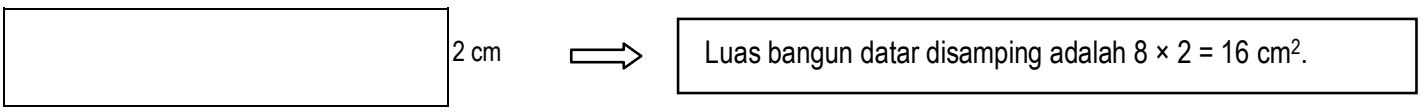

\section{Gambar 9. Persegi Panjang dengan Konsep Menemukan Luasnya dengan Cepat}

Eksplorasi ini dapat dilakukan dengan memberikan contoh lain (persegi panjang dengan ukuran berbeda, misalnya $4 \mathrm{~cm} \times 4 \mathrm{~cm}, 6 \mathrm{~cm} \times 6 \mathrm{~cm}, 8 \mathrm{~cm} \times 5 \mathrm{~cm}$ ). Dari proses eksplorasi tersebut siswa dapat dengan mudah menemukan sendiri kesimpulan. Sehingga jika diberikan gambar persegi panjang dengan ukuran "Panjang (cm)" dan "Lebar (cm)" seperti di bawah ini.

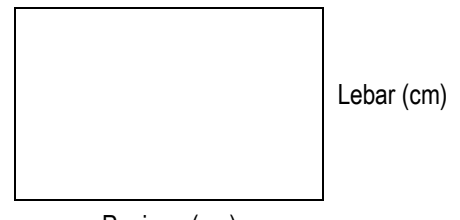

Panjang (cm)

\section{Gambar 10. Persegi Panjang Berukuran "Panjang (cm)" dan "Lebar (cm)"}

Siswa dapat menemukan hasil luasnya adalah panjang $\times$ lebar, sehingga siswa dapat menarik kesimpulan bahwa: luas persegi panjang $=$ panjang $\times$ lebar.

\section{KESIMPULAN}

Berdasarkan pemaparan pada hasil dan pembahasan, maka beberapa hal yang dapat disimpulkan dari penelitian dengan mengkaji konsep teori ini adalah Pembelajaran Matematika GASING sangat sesuai dengan falsafah teori-teori belajar yang berkembang hingga saat ini. Pembelajaran Matematika GASING sangat sesuai dengan pemikiran-pemikiran teori behavioristik, humanistik, kognitif, dan konstruktivistik, diantaranya sebagai berikut: 
1. Pembelajaran Matematika GASING sesuai dengan teori belajar behavioristik yang dikemukakan oleh Thorndike tentang hukum kesiapan, hukum latihan, dan hukum akibat. Dalam hukum kesiapan, kepuasan muncul ketika siswa merasa senang, mereka menemukan faktor AHA, bisa tertawa, terpuaskan rasa ingin tahunya/ faktor AHA, dan merasa gembira, yang merupakan ciri dari belajar menyenangkan. Dalam hukum latihan, siswa diberikan latihan secara lisan dan tertulis secara berulang-ulang untuk memperlancar kemampuan mencongaknya hingga lancar. Dalam hukum akibat ketika siswa mampu mengerjakan atau menjawab pertanyaan, maka diberikan pujian secara verbal dan non verbal.

2. Pembelajaran Matematika GASING sesuai dengan teori belajar humanistik pemikiran Combs, yaitu siswa memiliki perasaan senang yang membuat siswa belajar sesuai kemauan sendiri tanpa terpaksa.

3. Pembelajaran Matematika GASING sesuai dengan teori belajar kognitif pemikiran Kohler, yaitu belajar dilakukan dengan cara bermain dan mengeksplorasi dengan benda nyata atau alat peraga (tahap konkret). Dalam proses mental atau mencongak siswa juga dapat menemukan jawaban atas persoalan yang dihadapi. Jawaban ini ditemukan sendiri oleh siswa melalui faktor AHA (Insight).

4. Pembelajaran Matematika GASING sesuai dengan teori konstruktivistik Dewey, yaitu siswa terlibat aktif seperti yang terjadi pada proses pembelajaran tahap konkret, siswa melakukan hands on activity. Selain itu kesesuaian dalam teori konstrukvistik Piaget, siswa melibatkan indra penglihatan, pendengaran, perabaan, dan pengecapan dalam proses pembelajaran. Sebagai tambahan, teori konstruktivistik Bruner yaitu discovery juga sesuai dengan Pembeajaran Matematika GASING yang mana siswa dibimbing untuk menemukan konsep secara umum dari proses bukti secara induktif.

\section{REKOMENDASI}

Penelitian ini memberi batasan pada empat teori belajar yaitu behavioristik, humanistik, kognitif, dan konstruktivistik. Hal ini dapat menjadi gambaran apabila akan dilakukan peninjauan terhadap Pembelajaran Matematika GASING dari perspektif teori belajar yang lain.

\section{UCAPAN TERIMA KASIH}

Peneliti ingin mengucapkan terima kasih kepada rekan-rekan di Program Studi Pendidikan Matematika STKIP Surya atas bantuannya dalam menyediakan bahan-bahan kajian teori dan juga atas diskusi-diskusi yang telah dilakukan.

\section{DAFTAR PUSTAKA}

Hidayati, T. N. (2011). Implementasi Teori Belajar Gestalt pada Proses Pembelajaran. Jurnal FALASIFA. Vol. 2 No. 1: 1-19.

Ibrahim \& Suparmi. (2012). Pembelajaran Matematika Teori dan Aplikasinya. Yogyakarta: SUKAPress.

Kusuma, J. \& Sulistiawati. (2014). Teaching Multiplication of Numbers 1 to 10 to STKIP Surya Students Using Matematika GASING. IndoMS-JME (Journal of Mathematics Education) Vol. 5 No. 1: 66-84.

Laila, Q. N. (2015). Pemikiran Pendidikan Moral Albert Bandura. Modeling: Jurnal Program Studi PGMI. Vol. III No. 1: 21-36. 
Mihmidiya, N. (2013). Pengembangan Pembelajaran Matematika Berbasis Fase-Fase Belajar Gagne pada Operasi Hitung Bentuk Aljabar di Kelas VIII MTs Al Mukarromin Wadak Kidul Duduk Sampeyan Gresik. [Online] Tersedia: http://digilib.uinsby.ac.id/10582/5/bab\%202.pdf [5 Februari 2018]

Nahar, N.I. (2016). Penerapan Teori Belajar Behavioristik dalam Proses Pembelajaran. Nusantara (Jurnal IImu Pengetahuan Sosial). Vol. 1: 64-74. [Online]. Tersedia: http://jurnal.umtapsel.ac.id/index.php/nusantara/article/viewFile/94/94 [12 Februari 2018]

Sunaryo, Y., Nuraida, I., dan Zakiah, N. E. (2018). Pengaruh Model Pembelajaran Hybrid Tipe Traditional Clasess-Real Workshop terhadap Kemampuan Pemahaman Matematik Ditinjau dari Self-Confidence Siswa. Teorema: Teori dan Riset Matematika, Vol 2, No 2: 93100.

Surya, Y. (2013). Modul Pelatihan Matematika GASING SD Bagian 1. Tangerang: PT. Kandel.

Surya, Y. \& Moss, M. (2012). Mathematics Education in Rural Indonesia. Proceeding in the 12th International Congress on Mathematics Education: Topic Study Group 30, 6223-6229.

Triyanto, A. (2011). Teori-Teori Belajar. Online. Tersedia: http://staffnew.uny.ac.id/upload/132310879/pendidikan/06Teori+Belajar.pdf $\left[\begin{array}{ll}14 & \text { Januari }\end{array}\right.$ 2018] 
•54 Jurnal Teorema: Teori dan Riset Matematika Vol 4 No 1, Hal 54-54, Maret 2019 